\title{
ICT Availability and Usage by Farm women in Agriculture
}

\author{
Sarah Kamala, Uma Jyothi* and Neela Rani \\ All India Coordinated Research Project on Home Science Extension, Professor Jayashankar \\ State Agricultural University, Hyderabad-30 \\ *Corresponding author
}

\section{A B S T R A C T}

\section{Keywords}

Icts, Access to ICT, Agricultural development, Access to agricultural information

\section{Article Info}

Accepted:

12 October 2019

Available Online:

10 November 2019
ICTs (Information and Communication Technologies) are a varied set of technological tools and assets to generate, stockpile, produce value and manage information. It may consist of radio, television broadcasting, computer hardware, software services and electronic media. Recently, communication through ICTs is considered very important in enhancing farmers' access to better understand agricultural position and fast-tracking growth of agriculture in a developing country like India. There has been a rapid growth in the ICT sector and the use of ICT has expanded radically. Access to ICT means has possibility to make substantial influence in the empowerment of farm women and support their effort for improvement of production in various farm activities. Nowadays, the ICTs have generated an opportunity for the farmers specially to get the information about marketing and weather. Through this, they directly keep in touch with market personals and offer their produce with reasonable prices, and also keep them aware for weather forecast for agriculture input application like fertilizer and pesticides which might be affected by un fore seen disasters as communicated by metrological department. Even though women play a very important and essential role in agricultural development and allied fields, they have practically no access to agricultural information, services or production assets and have very limited control over their earnings. The present study is carried out to address the extent of farm women's access and availability to ICTs, the use of Icts by farm women, in the agriculture sector.

\section{Introduction}

Agriculture is the backbone of the Indian economy, out of which 56.6 per cent of the Indian population are dependents on agriculture (GoI, 2011b), agricultural growth is, therefore, crucial for raising economic development and feeding the growing population (Datt and Ravallion, 1996). However, one section that can be able to enhance agricultural production is the influence of information and knowledge. ICTs (Information and Communication Technologies) are a varied set of technological tools and assets to generate, stockpile, produce value and manage information. It may consist of radio, television broadcasting, computer hardware, software services and electronic media. The ICTs in current years have been observed main changes and are evolving as an 
influential device for accelerating agricultural growth in a developing country like India. There is also an increase in recognition of farmers and members of rural communities understanding the importance of knowledge, information and appropriate learning methods (Green Ridge, 2003, Lightfoot, 2003) in order to move towards development. Women farmers have been reported to be 20-30 per cent less productive than men (FAO, 2011). The less productivity among women farmers is recognized to be due to inadequate information and knowledge. Even though women farmers play a significant and crucial role in agricultural development and allied fields, they have no access to agricultural information, services or production assets and have very limited control over their earnings (Huyer and Carr, 2002). Aiming at benefit of women in agricultural production and to challenge the existing gender disparities in rural areas, considering women's access to ICTs, usage of ICTs by them, barriers for access, and the impact of ICTs on agricultural productivity and finally the empowerment of farm women is essential. Hence the present study was undertaken to address the extent of farm women's access and availability to Icts, the use of Icts by farm women, in the agriculture sector.

\section{Materials and Methods}

The study was conducted in the adopted villages of AICRP HSc, Maheswaram and Moinabad mandals of the Rangareddy districts of Telangana. From each of the selected taluks five villages were selected randomly. By applying simple random sampling technique 100 respondents were selected for the study. Primary data on access and other aspects of ICT and its usages by farm women were collected from the female respondents of the farm families through well-structured and pretested schedule. The information generated by PRA/group discussion complemented the questionnaire based information collected through personal interview. The data collected through a detailed interview schedule employing personal interview method. The responses were scored, quantified, categorized and tabulated using statistical methods like frequencies, percentage, mean, standard deviation and correlation

\section{Results and Discussion}

From the data it is evident that majority of the (48\%) of the members are Middle (36-50 yrs.) aged, thirty-seven (37\%) percent are young (18-35yrs) and fifteen percent (15\%) are Upper middle (50 yrs. and above) aged. From this it is evident that majority of the respondents were in the age group of 18 years to 50 years who are actively involved in farming.

Maximum (70.00\%) of the farm women were illiterates, almost equal number $(8.00 \%)$ of farm women had done their middle and up to $\mathrm{X}$ class level of education. Only negligible percentage $(2.00 \%)$ of the farm women had completed their graduation and above level of education. Highest $(86.67 \%)$ percentage of farm women were married, belonged to small family category with less than three members in the family followed by small level category (4-5 member) in the family $(83.00 \%)$ in the family viewing the lessening of joint and large families in now a day's societies with medium level land holding (Fig. 1-4 and Table 1-5).

\section{Extension contact}

\section{Regular contact}

Regular contact was reported only with NGO and Block personnel by a very little (2 and 1 ) percent of the respondents among all the extension agents. Contact with the Bank personnel was reported to be occasional by 11.00 percent of the respondents as they were 
active members of SHGs and gets contact with bank in their regular monthly activities of credit and debit of their funds. Followed by University Personnel 7 percent, extension officers 6 percent and then comes the block personnel with 5 percent of the respondents. Village level extension worker was reported to be never contacted by 100 percent members of the respondents.

\section{Organizational participation}

More than 80 percent $(89 \%)$ of the respondents participate in Self Help Group (SHGs) activities on regular basis as almost all members are active members of SHGs and these SHGs are very strong in combined Andhra Pradesh State and now in Telangana State. only negligible number of respondents participate either occasionally $(5 \%)$ or never (14\%).

Only three percent (3\%) attend Anganwadi centre as they have children between the age group of 2-5 years. Rest i.e. ninety-seven percent $(97 \%)$ of respondent's children crossed this age group as majority of them are in the age group of 35-50 years. Pregnant and lactating mothers are also not there among the respondents who avail the services of ICDS/ anganwadi centers.

There are no Mahilamandals in the state. After initiation of SHGs by the DRDA(District Rural Development Agency) and SERP (Society for Elimination of Rural Poverty) and with the World Bank initiated pilot projects all the poorest of the poor and other rural women were enrolled into SHGs network and hence other organizations working with women became non-functional.

Two of the respondents attend Gram Panchayat regularly as one member is Gram Panchayat President (Sarpanch/ Mukhya) and other two are Ward members. One member attends Zilla panchayat, as a member. No respondent attend Taluk panchayat, as none of them were elected to this office.

\section{Mass media ownership and frequency of use}

Television were owned by eighty-two (82\%), percent, and thirteen percent were viewing owned by others. only a negligible number of respondents i.e. 5 percent are not having T.V. This coincides with the research survey report of Bark India. Radios owned by 14 percent and great majority (58\%) were using it through other source i.e. owned by others. Due to the advancement of mobile phones transistor radios and other radios usage was decreased but after internet of FM radio in mobiles, Mobile radio was available with many people, so the respondents are listening to radios owned by others. According to India's premier television ratings agency survey, the Broadcast India Research Council, or Barc India (2016 and 2017), The new survey points to a significant increase in number of TV homes: TV owning homes in India have gone up from 153.5 million to 183 million. That is not all. Rural India has $17 \%$ more TV owning households than urban India. The urban-rural split in terms of percentage of TV penetration has changed from 49:51 to 46:54.

\section{Availability and accessibility to different ICTs hardware}

Majority (94) of the respondents have television as it is the cheapest and most common source of entertainment. Next most available ICT hardware was mobile (52) since in the present period a mobile has become necessity to everyone in day to day life. Radios were available only to 37 respondents as they are also available in inbuilt form of mobiles. Only a negligible number of respondent's i.e 1 is not having availability of 
internet and e-mail. Television is the most available ICT with complete access among 94 respondents followed by mobile with 52 member's complete access to it.36 respondents has partial access to the radios where as kioskis, CDs. Television and Mobile phones accessibility is higher as compared to other ICT tools as it is affordable, portable as well as useful during emergencies.

\section{Review of literature}

Rebekka Syiem and Saravanan Raj (2015) found that majority of the farmers owned mobile phones as well as television and radio while most frequently used ICT was mobile phone.

Mobile phones were widely used by the farmers for social communication, contacting middle men for the marketing of produce and contacting experts on real time basis for getting agricultural advisories.

Farmers also reported that mobile phones proved to be useful during health emergencies. Information services on availability of inputs, quality of inputs, and pest and disease.

Rajni Jain et al., (2012) reported that radio and TV played a significant role in disseminating the information regarding prices, technology inputs and crop protection measures. But for animal health, phone was the major source of communication by the farmers of Sonipat, Haryana.

Olaniyi (2013) and Chhachar et al., (2014). evidenced in his research findings that mobile phones, radio and television are the most important tools of communication which can be accessed by farmers for agricultural related information and knowledge Particularly, telephone facility (including mobile phones) has been reported to increase the opportunity of getting access to the people living in rural areas.

Gupta (2005) reported that 86 per cent of the farmers had access to a mobile phone which therefore contributed towards developing farmer's linkage with other people including extension experts.

Sharma et al., (2012) pointed that about 98.3 per cent of the farmers in Punjab, India possessed mobile phones. This indicated that there is an increased penetration of ICTs among rural populations and therefore if appropriately used it can offer huge scope for development in rural areas.

Ansari and Pandey (2011), noted that around 83.34 per cent of the farmers in Uttarakhand, India owned mobile phones for more than two years Which has been their major means regarding the farming activities and information.

The results of the study revealed that the level of availability and accessibility of ICTs was the highest for television followed by mobile phones and radio respectively. Television and Mobile phones were also regarded as the most frequently used ICT tool as compared to other ICTs. The reason mobile phones were highly accessed and most frequently used by majority of the respondents is that it is easily affordable and could be easily used by even illiterate farmers. The study has found that lack of confidence in operating ICTs, erratic power supply, low network connectivity, lack of awareness of benefits of ICTs, lack of skill in handling ICTs, low ICT literacy, lack of repairing facilities, attitudinal barriers towards ICTs, poor finance, lack of training and practical exposure, high cost of repairing ICTs and insufficient regional language were the major constraints faced by the farmers in the effective use of ICTs. 
Table.1 Distribution of the respondents according to their profile

\begin{tabular}{|c|c|c|c|c|}
\hline & & & & $N=100$ \\
\hline SI No. & Characteristics/Attributes & Category & Frequency & Percentage \\
\hline \multirow[t]{3}{*}{1} & \multirow{3}{*}{ Age } & Young( 18-35yrs.) & 37 & 37.00 \\
\hline & & Middle(36-50 yrs.) & 48 & 48.00 \\
\hline & & $\begin{array}{l}\text { Upper middle ( } 50 \text { yrs. and } \\
\text { above) }\end{array}$ & 15 & 15.00 \\
\hline \multirow[t]{4}{*}{2} & \multirow[t]{4}{*}{ Caste } & Gen & 23 & 23.00 \\
\hline & & OBC & 37 & 37.00 \\
\hline & & ST & 11 & 11.00 \\
\hline & & $\mathrm{SC}$ & 29 & 29.00 \\
\hline \multirow[t]{9}{*}{3.} & \multirow[t]{9}{*}{ Education } & Illiterate & 70 & 70.00 \\
\hline & & Can read and write & 3 & 03.00 \\
\hline & & Primary & 1 & 01.00 \\
\hline & & Middle & 8 & 08.00 \\
\hline & & Up to class $\mathrm{x}$ & 8 & 08.00 \\
\hline & & HSLC passed & 2 & 02.00 \\
\hline & & Higher secondary passed & 6 & 06.00 \\
\hline & & Graduate & 2 & 02.00 \\
\hline & & Post Graduate & 0 & 00.00 \\
\hline \multirow[t]{4}{*}{4.} & \multirow[t]{4}{*}{ Marital status } & Married & 100 & 100.00 \\
\hline & & Unmarried & 0 & 0.00 \\
\hline & & Widow & 0 & 0.00 \\
\hline & & Divorcee & 0 & 0.00 \\
\hline \multirow[t]{11}{*}{5.} & Occupation & & & \\
\hline & \multirow[t]{5}{*}{ i) Main occupation } & Farming & 77 & 77.00 \\
\hline & & Service & 3 & 03.00 \\
\hline & & Farm allied & 0 & 0.00 \\
\hline & & Business & 0 & 0.00 \\
\hline & & Daily wage earner & 20 & 20.00 \\
\hline & \multirow[t]{5}{*}{ ii) Subsidiary occupation } & Farming & 20 & 20.00 \\
\hline & & Service & 9 & 09.00 \\
\hline & & Farm allied & 4 & 04.00 \\
\hline & & Business & 9 & 09.00 \\
\hline & & Daily wage earner & 58 & 58.00 \\
\hline \multirow[t]{3}{*}{6.} & \multirow[t]{3}{*}{ Type of family } & nuclear & 92 & 92.00 \\
\hline & & joint & 5 & 05.00 \\
\hline & & extended & 3 & 03.00 \\
\hline \multirow[t]{3}{*}{7.} & \multirow[t]{3}{*}{ Size of family } & Small & 83 & 83.00 \\
\hline & & Medium & 14 & 14.00 \\
\hline & & large & 3 & 03.00 \\
\hline \multirow[t]{3}{*}{8.} & \multicolumn{4}{|c|}{ Organizational participation } \\
\hline & i) Type of membership & Member & 97 & 97.00 \\
\hline & & Office bearer & 3 & 03.00 \\
\hline
\end{tabular}


Table.2 Distribution of respondents according extension contact

\begin{tabular}{|c|c|c|c|c|c|c|}
\hline \multirow{2}{*}{ Extension Agent } & \multicolumn{2}{|c}{ Regularly } & \multicolumn{2}{c|}{ Occasionally } & \multicolumn{2}{c|}{ Never } \\
\cline { 2 - 7 } & F & \% & F & \% & F & \% \\
\hline VLEW & 0 & 00.00 & 0 & 0.00 & 100 & $\mathbf{1 0 0 . 0 0}$ \\
\hline Extension Officer & 0 & 0.00 & 6 & 06.00 & 94 & $\mathbf{9 4 . 0 0}$ \\
\hline University Personnel & 0 & 0.00 & 7 & 07.00 & 93 & $\mathbf{9 3 . 0 0}$ \\
\hline NGO Personnel & 2 & 02.00 & 1 & 01.00 & 97 & $\mathbf{9 7 . 0 0}$ \\
\hline Bank Personnel & 0 & 0.00 & 11 & 11.00 & 89 & $\mathbf{8 9 . 0 0}$ \\
\hline Block Personnel & 1 & 01.00 & 5 & 05.00 & 94 & $\mathbf{9 4 . 0 0}$ \\
\hline Any other & $\mathbf{0}$ & $\mathbf{0 . 0 0}$ & $\mathbf{0}$ & $\mathbf{0 0 . 0 0}$ & $\mathbf{0}$ & $\mathbf{1 0 0 . 0 0}$ \\
\hline
\end{tabular}

Table.3 Percent distribution of respondents according to organizational participation

\begin{tabular}{|c|c|c|c|}
\hline \multicolumn{2}{|c|}{ No 100 } \\
\hline \multirow{2}{*}{ Organization } & \multicolumn{3}{|c|}{ Extent of participation } \\
& \multicolumn{3}{|c|}{ Never } \\
\hline Self Help Group & Regularly & Occasionally & 14.00 \\
\hline Anganwadi centre & 81.00 & 05.00 & 97.00 \\
\hline Mahilamandals & 03.00 & 00.00 & 100.00 \\
\hline Gram Panchayat & 0.00 & 0.00 & 97.00 \\
\hline Zilla panchayat & 02.00 & 01.00 & 99.00 \\
\hline Taluk panchayat & 01.00 & 00.00 & 100.00 \\
\hline Any other & 0.00 & 0.00 & 0.00 \\
\hline
\end{tabular}

Table.4 Distribution of respondents according to their Mass media ownership and frequency of use

\begin{tabular}{|c|c|c|c|c|c|c|c|}
\hline \multicolumn{8}{|c|}{$\mathbf{N}=100$} \\
\hline \multirow[t]{2}{*}{ Mass media } & \multirow{2}{*}{$\begin{array}{c}\text { Owned } \\
\%\end{array}$} & \multirow[b]{2}{*}{$\begin{array}{c}\text { Other } \\
\text { Source } \\
\text { (use owned } \\
\text { by others) } \\
\%\end{array}$} & \multirow[b]{2}{*}{$\begin{array}{l}\text { Neither } \\
\text { Owned } \\
\text { Nor } \\
\text { Using } \\
\text { Other } \\
\text { Sources }\end{array}$} & \multicolumn{4}{|c|}{ Frequency of use } \\
\hline & & & & Always & Sometimes & Rarely & Never \\
\hline Radio & 14.00 & 58.00 & 28.00 & 1 & 1 & 59 & 39 \\
\hline Television & 82.00 & 13.00 & 5.00 & 76 & 13 & 4 & 7 \\
\hline News paper & 10.00 & 02.00 & 88.00 & 7 & 3 & 4 & 86 \\
\hline Magazines & 01.00 & 00.00 & 99.00 & 2 & 0 & 1 & 97 \\
\hline $\begin{array}{c}\text { Others } \\
\text { (Journals, } \\
\text { leaflets, booklets } \\
\text { etc.) }\end{array}$ & 00.00 & 00.00 & 100.00 & 0 & 0 & 0 & 100 \\
\hline
\end{tabular}


Table.5 Distribution of respondents according to availability and accessibility to different ICT shardware

\begin{tabular}{|c|c|c|c|c|c|}
\hline \multirow{2}{*}{ ICTs hardware } & \multicolumn{2}{|c|}{ Availability } & & \multicolumn{3}{c|}{ Extent of Access } \\
\cline { 3 - 6 } & & & Complete & Partial & No access \\
\cline { 3 - 6 } & Yes & No & & & \\
\hline Television & 94 & 6 & 70 & 5 & 25 \\
\hline Radio & 37 & 63 & 30 & 5 & 34 \\
\hline Mobile & 52 & 48 & 57 & 0 & 100 \\
\hline $\begin{array}{c}\text { Kiosk / common } \\
\text { service centers }\end{array}$ & 0 & 100 & 0 & 0 & 100 \\
\hline Computer & 0 & 100 & 0 & 0 & 100 \\
\hline CD/VDV & 0 & 100 & 0 & 0 & 100 \\
\hline Internet & 1 & 99 & 0 & 0 & 100 \\
\hline e- mail & 1 & 99 & 0 & & 0 \\
\hline
\end{tabular}

Fig.1

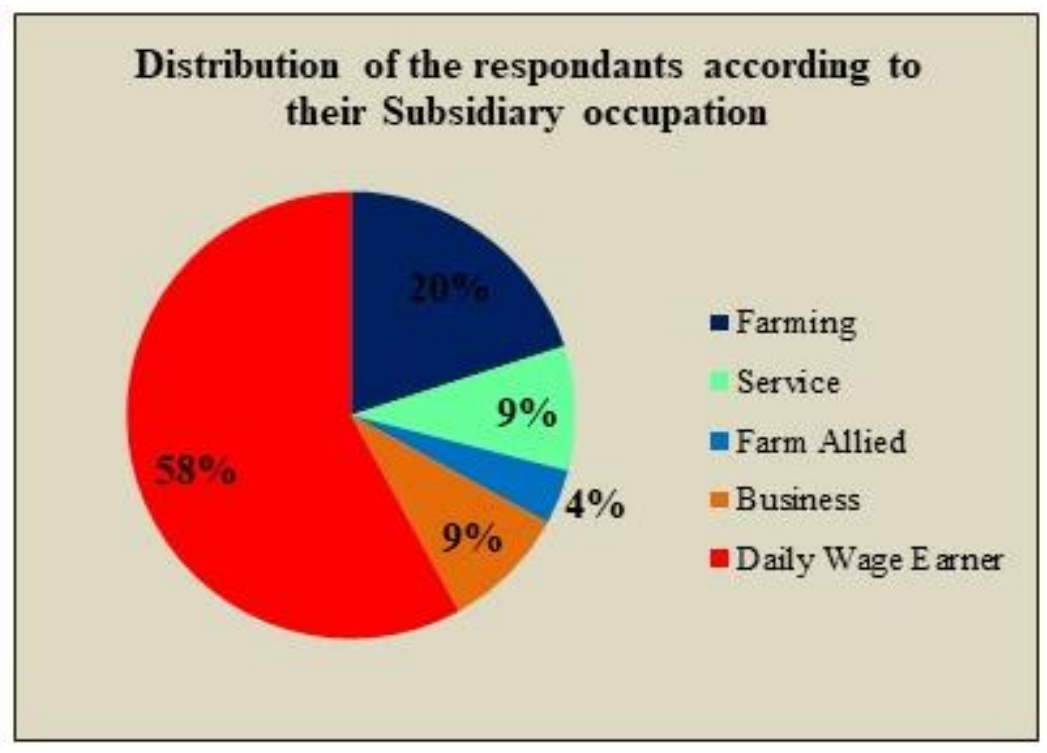


Fig.2

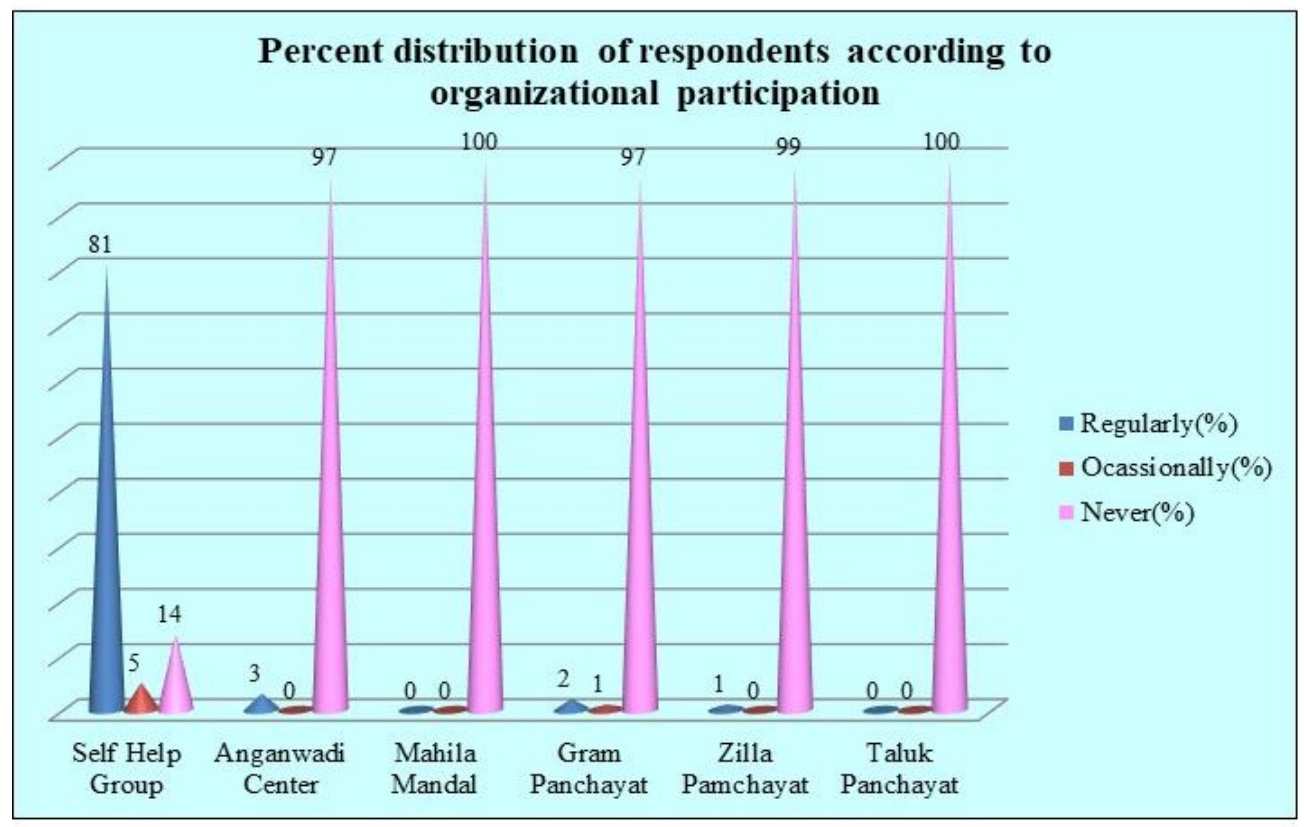

Fig.3

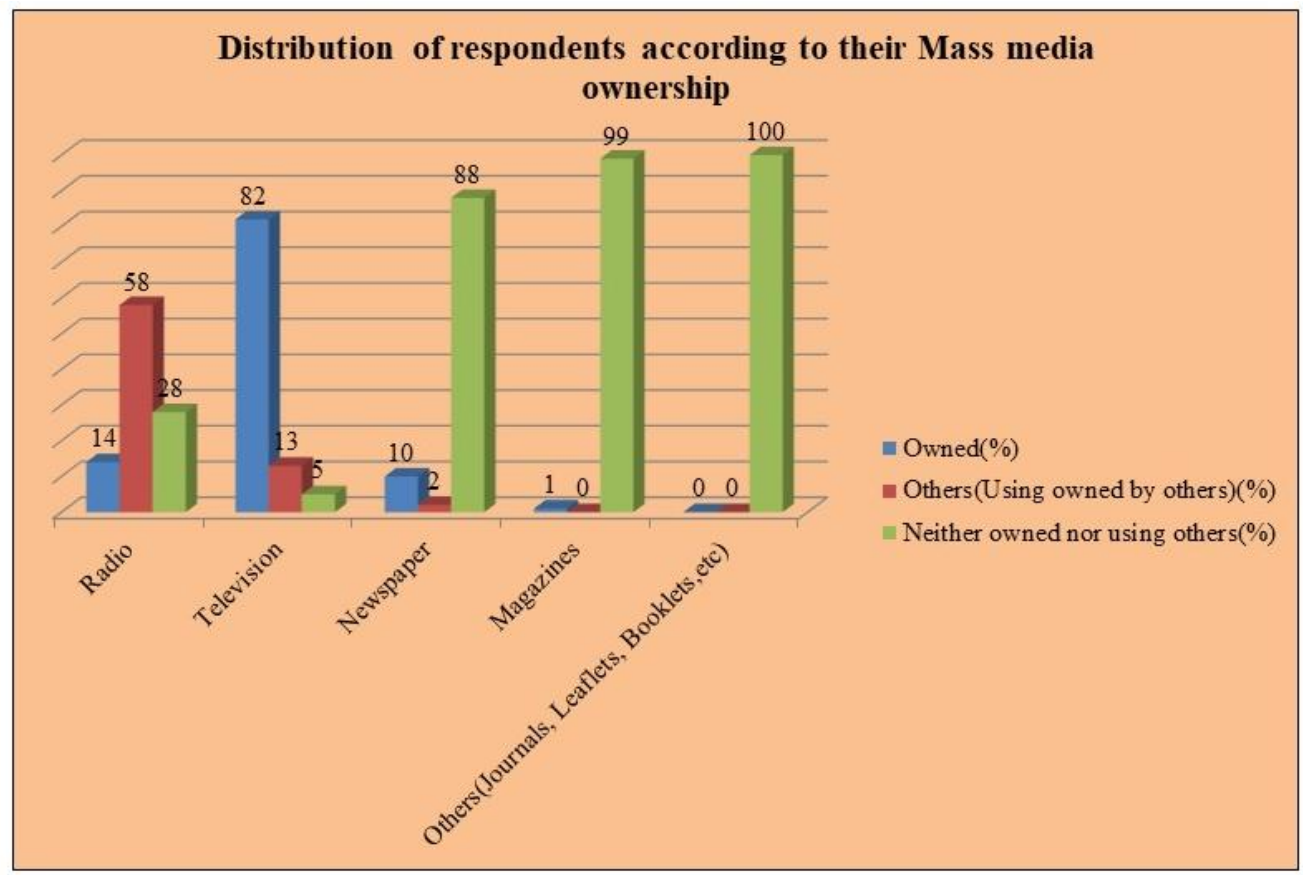


Fig.4

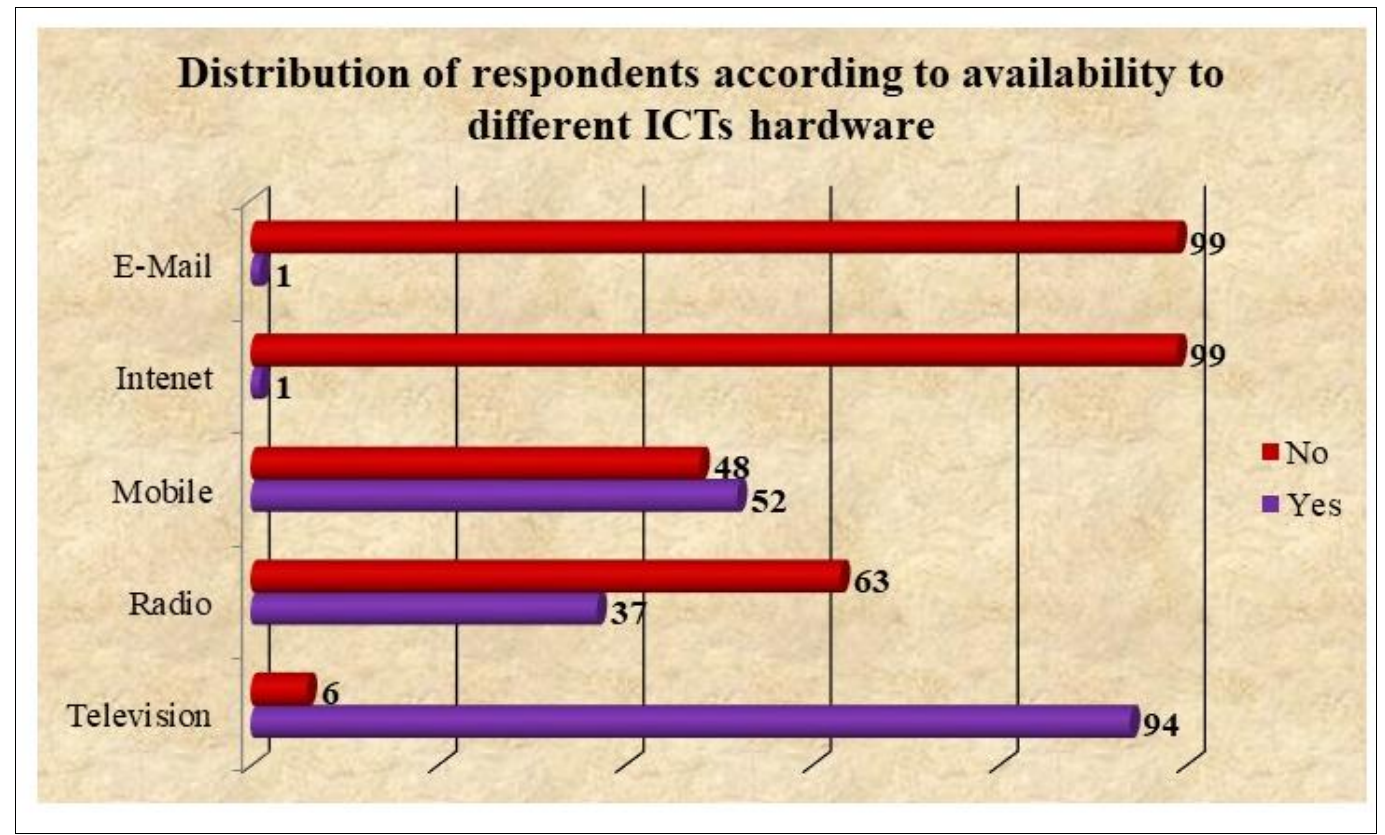

Based on the findings of the study, the following recommendations were also made:

Dissemination of agriculture-related information through F.M radio programmes would be recommended. More awarenesscum-training programmes on ICTs should be encouraged among farmers by agricultural state departments, research organizations and its allied departments in order to increase the confidence, competence and skill in using ICTs for development. Increased engagement in social media among rural youths on farming in order to enhance the communication pattern among themselves and extension personnel. Since there is lack of repairing Centres of ICTs at the village level, vocational training for the youths on ICT infrastructure would be recommended.

\section{References}

Ansari, M.A. and Pandey, N. (2011) Assessing the potential and use of mobile phones by the farmers in Uttarakhand (India): A special project report. G.B. Pant University of Agriculture and Technology, Pantnagar, India.

Chhachhar, A.R., Querestic, B., Khushk, G.M. and Ahmed, S. (2014) Impact of ICTs in Agriculture Development. Journal of Basic Applied Scientific Research, 4(1): 281-288. http://www.textroad.com/ pdf/JBASR/J.\%20Basic.\%20Appl.\%20Sci \%20Res.,\%204(1)281-288,\%202014.pdf.

Datt and Ravallion, (1996) The World Bank Economic Review, Volume 10, Issue 1, January 1996, Pages 125, https://doi.org/10.1093/wber/10.1.1

GoI. (2011b) Economic activity. Government of India.

Greenridge, C. (2003). Welcome Address: ICTs Transforming Agricultural Extension? Presentation to CTA's Sixth Consultative Expert Meeting of its Observatory on ICTs. Wageningen, the Netherlands: CTA. [Online] Available: www.cta.int/observatory 2003/keynote_papers/Welcome.pdf. 
Gupta, D.K. (2005) Modern encyclopedia of media and mass communication. Rajat Publications, New Delhi, India.

Huyer and Carr (2002). Information and Communication Technologies: A Priority for Women Article in Gender Technology and Development 6(1):85100.

Lightfoot, C. (2003). Demand-driven extension: some challenges for policy makers and managers. Presentation to CTA's Sixth Consultative Expert Meeting of its Observatory on ICTs. Wageningen, the Netherlands: CTA. [Online] Available: www.cta.int/ observatory2003/ keynote_papers/ Challenges_in-demanddriven _extension.pdf

Oyeyinka, R.A. and Bello, R.O. (2013)

Farmers Use of ICTs for Marketing
Information Outlets in Oyo State, Nigeria. Journal of Agricultural Science, 5 (11):150-158.doi: 10.5539/jas.v5n11p150

Rajni Jain, Usha Rani Ahuja and Anjani Kumar (2012), Indian. Journal n. of Agricultural. Economics. Vol.67, No. 3, July-Sept. 2012.

Rebekka Syiem1, Saravanan Raj (2015) Journal of Agricultural Informatics (ISSN 2061-862X) 2015 Vol. 6, No. 3: 24-41.

Sharma, M., Kaur, G. and Gill, M.S. (2012) Use of Information and Communication Technology in agriculture by farmers of Kapurthala District Journal of Krishi Vigyan Kendra, 1(1): 82-89.

\section{How to cite this article:}

Sarah Kamala, uma Jyothi and Neela Rani. 2019. ICT Availability and Usage by Farmwomen in Agriculture. Int.J.Curr.Microbiol.App.Sci. 8(11): 1620-1629. doi: https://doi.org/10.20546/ijcmas.2019.811.187 